\title{
The Impact of Invasive Aliens Species of Plant in Dryland Crop Production
}

\author{
Suyud Warno Utomo, Priyaji Agung Pambudi
}

\begin{abstract}
The existence of invasive alien species (IAS) in an ecosystem has become a global issue that continues to be discussed. Invasive plants led to the dominance of the crop in the fulfillment of competition for nutrients, water, light, and pollinated by pollinators. In Indonesia there are 27 IAS that is very dangerous and threatens the stability of the ecosystem. The introduction of IAS in Indonesia generally lowers production reached $20 \%, 1$ individual IAS in the area of $0.1 \mathrm{~m}^{2}$ can reduce $57 \%$ of agricultural production. This aims to determine the introduction of IAS and its impact on agricultural. The method used is the analysis of vegetation, a literature review of national and international journals and complemented by interviews was conducted in June-October 2018 in Pacitan, East Java. Based on the research known biodiversity in the study site was (2.99) and Evenness medium $(e '=0.41)$ with the third-highest family Compositae (IVIs = 53.1), Poaceae (IVIs = 41.16), and Amaranthaceae (IVIs = 23.97). Cyperaceae and Compositae is the most dominant and is found throughout the agricultural types in the sites. Compositae is dominating (IVIs = 53.1). Alternanthera sessilis (IVIs $=23.97)$, Cyanthillium cinereum $($ IVIs $=1.45)$, and Ecinochloa colona $($ IVIs $=12.33)$. Based on the concept of IAS disturbance caused interference in terms of the type, intensity, spatial reach, frequency, and other factors are interspecific. According to the concept of disturbance the solution is control the growth and spread of IAS to save the ecosystem and agriculture sustainability.
\end{abstract}

Keywords: crop production; ecosystem; invasive alien species; organism interaction.

\section{INTRODUCTION}

$\mathrm{I}_{\mathrm{n}}$ ndonesia is known as a very fertile agricultural country with the support of potential bio-geographic conditions. This condition is a factor driving the majority of Indonesian people rely on agriculture [1]. The agricultural sector also contributes significantly to the economy of Indonesia with $11.02 \%$ of GDP. During the period 2010-2014, the average contribution of the agricultural sector to GDP reached $10.26 \%$ with a growth of about $3.90 \%$ [2]. As far as agriculture is still the sector is important and one of the foundations in realizing national economic development. This happens because agriculture has a strategic role in providing food, industrial raw materials, a contributor to GDP, foreign exchange earnings, the main employer, the main income source for rural households, providers of

Revised Manuscript Received on January 5, 2020.

* Correspondence Author

Suyud Warno Utomo*, School of Environmental Science, University of Indonesia and Department of Environmental Health, Faculty of Public Health University of Indonesia, Depok, Indonesia.

Email: suyudwarno@gmail.com

Priyaji Agung Pambudi, School of Environmental Science, University of Indonesia, Jakarta, Indonesia. Email: priyajiagungpambudi@gmail.com animal feed, and bioenergy [3]. However, the sustainability of agriculture, especially food crops in Indonesia are in serious threat.

The threat can be seen on the terms of the agricultural statistical data in 2016 that showed that the productivity of several agricultural commodities namely rice decreased $-1.48 \%,-3.95 \%$ soybean, peanut $-0.90 \%,-4.85 \%$ cassava, and sweet potatoes $-8.92 \%$ [4]. The decline in agricultural production is due to the presence of invasive plants [5]. Invasive plants into the cultivation of plant pests and if not controlled will continue to threaten agricultural production. Invasive plants are fundamentally alien plant species are intentionally or accidentally enter and/or entered an area outside its natural habitat, which can be called by a new habitat. The new habitat is actually not a native habitat for invasive plants, but because of the excellent adaptability, the types of invasive can grow and develop optimally [6]. Moreover, invasive species capable of dominating a region and hinder the growth and development of other local species [7]. But not many people who understand comprehensively and holistically about the mechanism of the disruption caused by invasive plants.

Invasive plants are one of the biotic factors inhibiting recovery of high yields in food crop cultivation system [8]. The existence of serious invasive plants and harmful impact on agricultural ecosystems due to dominating the ecosystems in which species grow. Dominance posed competition for resources such as nutrients, light, space, and water) $[9,10]$. Because of these mechanisms, then invasive alien has physiological and ecological advantages. The advantages of invasive alien species encourage domination in all parts of the ecosystem outside their natural habitat, causing the original type of pressure and lead to death or even extinction [11].

Extinction of local species is also caused by the competition mechanism of insect pollination pollinator [12]. This is caused because of some invasive plant species have shapes and floral display more exotic and able to attract insect pollinators. This resulted in the frequency of attendance at local plant-insect pollinator decline and direct impact on the amount of the resulting production [13]. Also, invasive plants can cause structural changes in the soil, the decomposition process, and soil moisture [14]. Given the dominance of invasive plants result in crops can not grow and develop optimally [15]. The impact is very dangerous if left unchecked, therefore, it needs to be controlled so that its presence can be controlled and minimized its spread. Control of invasive plants needs to begin by researching to determine the most dominant invasive plants in agricultural ecosystems and analyze their interaction with the cultivated plants as the basis for the determination

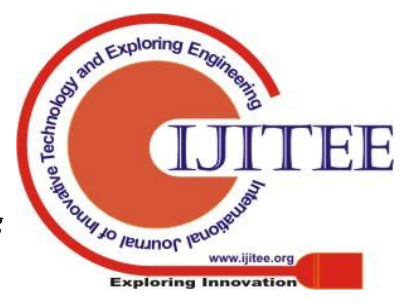


of control measures to achieve sustainable agricultural production to create food security.

Food security needs to ensure the quality of life and welfare of the community. However, it should be understood that food security includes three main aspects, namely adequacy, independence, and sovereignty [16]. Weeds become one of the factors affecting agricultural production in addition to soil fertility, crop rotation and agricultural patterns, treatments, quality of seeds, fertilizer, and land area [17, 18]. The difference is that weeds have a negative impact, while other factors have a positive impact on production. Agricultural production will be optimal if these factors can be managed properly. The management question is to optimize the positive factors and negative factors that suppress them. It needs to be optimized, for controlling pests, especially weeds produce emission of $4.4 \mathrm{~kg} \mathrm{CO} 2 \mathrm{eq} / \mathrm{ha} \mathrm{[19].} \mathrm{Therefore,}$ Therefore, the existence of invasive plant species raises very complex problems for the ecosystem.

\section{METHOD}

This study uses a quantitative approach to combined methods (mixed method). Quantitative methods conducted through observations using plots measuring 1 x 1 meter 120 plots spread Ngadirojo and District Sudimoro, Pacitan, East Java. Observations were made during eight months (July 2018-March 2019) and represented the dry season and the rainy season. The mechanism was chosen to obtain comprehensive research data because it is a possible invasive plant community structure on the two different seasons. Therefore, observations in two different seasons will give you a complete picture of the condition of the ecosystem related to the presence of invasive plants. Then the qualitative method is done through a literature review of national and international journals, books, and institutional reports related fields. The whole literature studied by researchers combined to obtain comprehensive information. Reader studied by a special investigator to determine and identify climate patterns in the study site during the last 10 years (2008-2018). The results of the literature review analyzed using descriptive exploratory analysis and analysis of the concept of ecological theory sixth in the disturbance or interference.

\section{RESULT AND DISCUSSION}

\section{A. Invasive Plant Diversity in Agriculture Agricultural Land}

Based on the observations found their 33 invasive plant species consisting of 15 families. If viewed in detail, then the family Poaceae has the highest number 7 Compositae species and 6 species. While the Compositae family has the largest INPj value ie $52.48 \%$. Invasive plants in detail the data found in the study site shown in Table 1.

Table 1. Importance value index 5 highest invasive plants

\begin{tabular}{|c|l|l|c|c|}
\hline No & \multicolumn{1}{|c|}{ Family } & \multicolumn{1}{|c|}{ Species } & INPj & $\mathrm{H}^{\prime}$ \\
\hline 1 & Amaranthaceae & $\begin{array}{l}\text { Alternanthera sessilis } \\
\text { (L.) R.Br. Ex DC. }\end{array}$ & 23.97 & 0,293 \\
\hline 2 & Compositae & $\begin{array}{l}\text { Emilia sonchifolia } \\
\text { (L.) DC. ex DC. }\end{array}$ & 12.39 & 0.187 \\
\hline 3 & Compositae & Cyanthillium & 13.45 & 0.196 \\
\hline
\end{tabular}

Based on Table 1. Important Value Index is known that invasive plant species as a whole amounted to 199.95 and a diversity index of 2.99 , which means that the diversity of invasive plants in the region were appropriate criteria for the 1-3. The high diversity of invasive plants in this region is strongly influenced by the opening of access. As the results of Hulme [20] which states that the current transport becomes a major factor that facilitates the spread of invasive plants. This is reinforced by the conditions at the site of research where the farmland in a valley surrounded by residential communities and roads located in the middle of farmland. Therefore,

Plant diversity in the medium category and/or high in dryland farming shows that there are not ideal conditions for the cultivation of agricultural land should have low diversity. This happens because farmers only grow better crops and horticultural crops so that other plant's existence is not expected. Plants are not expected existence will continue to be controlled. This shows that when plants diversity on dryland agricultural ecosystems were, then the land is not in a good state. The condition is caused by plant pests which resulted in competition with different crops so that growth and development will be disrupted. This finding is consistent with the statement Mardiyanti et al. [21] which states that agricultural ecosystems tend to have a low diversity with a particular plant species. The condition is caused by the intervention of farmers as managers of agricultural land. Fundamentally only want crop farmers who live on farms, while another plant has no real benefit and interfere with land management. Therefore, its existence is trying to control. while other plants have no real benefit and interfere with land management. Therefore, its existence is trying to control. while other plants have no real benefit and interfere with land management. Therefore, its existence is trying to control.

Based on the findings of research showing the location of its diversity being, it does not mean that the farmer does not seek to control it. However, due to natural factors beyond the ability of farmers to control the presence of plant pests, so that diversity is still being even 0:01 point of the high category though controlled.

\section{B. Dryland Agriculture Production}

Based on the results of the inventory of secondary data, it is known that the production of agricultural commodities fluctuated dry land. Below in Figure 1 is shown data on the average data 5 leading commodity agricultural production in the research area.

Based on Figure 1 note that from 5 commodity dryland farming of cassava has the highest average production in 2016 amounted to 19.43 tonnes/ha. Meanwhile, peanuts and soy is a commodity with the lowest production of 1.2 tons/ha and $1.25 \mathrm{t} / \mathrm{ha}$. The phenomenon is quite interesting that the corn crop in 2015 and 2016 production is 0 , meaning that the corn in this region is no longer grown by the community. When viewed in general 5 
seed dryland agriculture commodities are entirely decreased. Dryland agriculture production decline caused by many things such as the presence of invasive plants or plant pests, soil fertility, crop rotation, cropping, maintenance, quality seeds, fertilizer, and land area [22-24].

Based on the results of Fuel (2004) existence of invasive plants or invasive plants became one of the factors causing the decline in agricultural production. The study reinforced by research from Kilkoda et al. [25] that plant pests pose very serious competition in getting water, nutrients, sunlight, and a place to grow. Specifically, it is not known how much impact the presence of invasive plants to the decline in agricultural production in the research area, due to factors other than the presence of invasive plants is not controlled.

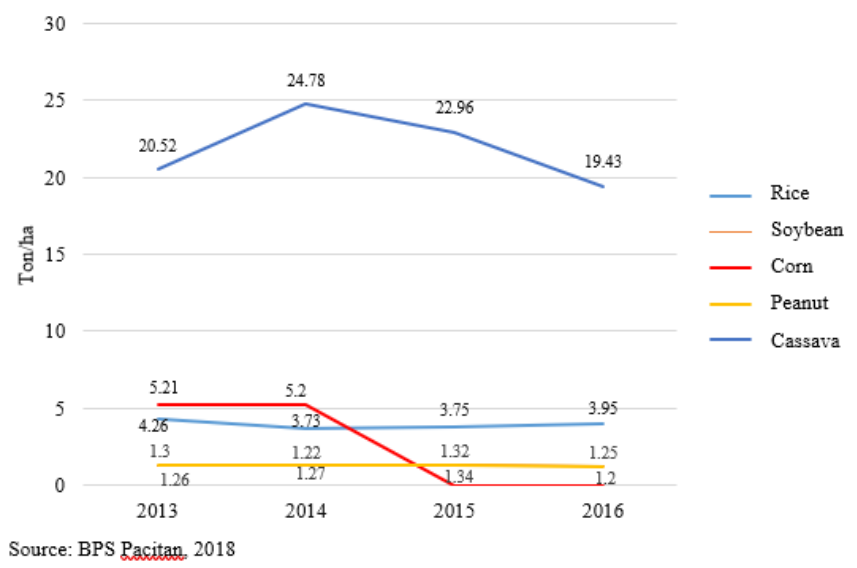

Figure 1. Average production 5 superior agricultural commodities dryland

\section{Interaction of invasive plants in agricultural ecosystems}

Environmental conditions become one of the important things in the process of growth and development of organisms. In particular, the environmental conditions were most responsible for the growth and development of organisms (plants) are nutrients. This is consistent with the concept presented by Zulharman [26] that the availability of enough nutrients around the plant cultivation influences the pattern of spread of invasive plants. Thus it can be said that fertile agricultural land has a greater potential for overgrown with invasive species. Therefore, Raghubanshi et al. [27] assert that invasive species can cause structural changes in the soil profile, decomposition, soil nutrient availability and soil moisture through the mechanism of growth and development.

The existence of plants at the same time and place gives rise to competition factors supporting the fulfillment of life getting bigger so that all plants will be competing to meet the needs for nutrients, water, and light for photosynthesis. On the other hand by following the concept that the wider ecology of plant canopy cover will lower the local temperature and then directly proportional to the moisture. This is by following the basic concept that serves to block the plant canopy of sun exposure on the surface of the soil and the changing patterns of evapotranspiration due to the number of plants that more and more so that the temperature of the soil surface will tend to be stable or even decreased and the humidity will be proportional. Another impact that arises is the change of decomposition and soil structure. If reviewed in-depth ultimately invasive plants provide more decomposition stock at the time of her death. Thus the greater the input of carbon for biogeochemical cycles in ecosystems that are synthesized by the micro, meso and macrofauna soil of invasive plant litter decomposition process. Then in terms of soil structure will also change due basically holding capacity between soil particles is influenced by the type and abundance of invasive plant roots.

Interaction of invasive plants with agricultural ecosystems show that each component of the ecosystem interacts negatively or positively. Therefore the existence of crops and plants around it is inseparable in the agricultural ecosystem. However, they still will interact with each other in life only in terms of the fulfillment of the factors supporting the growth but also the competition in terms of reproduction. According to Nel et al. [28] the presence of invasive plants become competitors of other plants that can reduce pollination by insects. The statement was supported by Gross et al. [29] which states that an estimated more than $85 \%$ of plants in the world take the role of insect pollinators. Pattison et al. [30] stated that the presence of invasive alien plants can affect vegetation dynamics. Broadly speaking invasive plant interactions with ecosystems tend to be negative. This is corroborated by the concepts put forward [31] that the impact caused by invasive species tend to be negative because it triggers the loss of biodiversity, loss of economic production, food security, water supply, regional stability, poverty, and migration.

\section{CONCLUSION}

Invasive plant diversity in dry agricultural land classified as moderate by the value $H^{\prime}=2.99$ consisting of 33 species from 15 families. Found family Poaceae has the highest number 7 Compositae species and 6 species. While the highest importance value index family Compositae obtained by $52.48 \%$ andAlternanthera sessilis (L.) R.Br. Ex DC. is the type with the highest importance value index 23.97. At the study site, there are 5 types of dryland agriculture commodities featured the upland rice, soybeans, peanuts, corn, and cassava. In general, when compared to the years 2013 and 2016 across the main commodity is experiencing a decline in production. The existence of invasive plants into one factor contributing to the decline in production, but not yet measured how much impact invasive plants to lower production.

\section{REFERENCES}

1. Hendrawan, F.J.T. (2016). Impact Analysis of Agricultural Land Transfer Function Against Being Region Farmers' Income Housing Puncel Dusun Desa Wetan Deket Lamongan. Journal, 1, 1-10

2. Central Bureau of Statistics. (2014). Statistics Indonesia 2014 Jakarta: The Central Bureau of Statistics

3. Agricultural Statistics. (2016). Agricultural Statistics. Jakarta: Ministry of Agriculture of the Republic of Indonesia

4. Agricultural Statistics. (2016). Agricultural Statistics. Jakarta: Ministry of Agriculture of the Republic of Indonesia

5. Pasandaran, E., Nursyamsi, D., Suradisastra, K., Mardiayanto, S., \& Haryono. (2015). Agricultural Development Based On Ecoregion Jakarta: IAARD Press.

6. Stefanowicz., A.M., Stanek, M., Majewska, M., \& Zubek, S. (2019). Invasive plant species identity affects soil microbial communities in a mesocosm experiment. Applied Soil Ecology, 136, 168-177

7. Sun, S.S., Wang, H.Z., Chen, Y.Z., Lou, J., Wu, L.S., Xu, J.M.

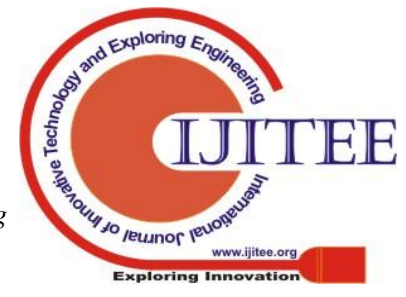


2019. Salicylate and phthalate pathways contributed differently on phenanthrene and pyrene degradations in Mycobacterium sp. WY10. J. Hazard. Mater, 364, 509-518.

8. Solfiyeni., Samsuari. \& Chairul. (2015, November). Invasive foreign plant diversity in the Andalas University Biology (HPPB) education and research forest. National Bioscience Seminar 2, Udayana University, Bali.

9. Utami, S., \& Purdyaningrum, LR (2012). Weed Community Structures Rice (Oryza sativa L.) Rice Rice Organic and Inorganic in Ketapang village, district. Susukan, Kab. Semarang, BIOMA, 14, 2, 91-95

10. Sadili, A., Sunaryo., Girmansyah, D. (November, 2015) Composition Analysis of Flora At Some type Dominant Invasive Plant In West Bali National Park, Bali. National Seminar on Biosciences 2 Udayana University, 21-31

11. Radosevich, R., Anoop, V.K., Joy, K., \& Arjun, C.P. (2017). Born Planta invasive or Bane to the Lepidopteron Fauna: Conservation and Suggestions Plant Management.

12. Charlebois, J.A. \& Sargent, R.D. (2017). No consistent pollinator-mediated impacts of alien plants on natives, Ecology Letters, $20,1479-1490$

13. Gross, C.L., Whitehead, J.D., Souza, C.S.d., \& Mackay, D.(2017). Unsuccessful introduced biocontrol agents can act as pollinators of invasive weeds: Bitou Bush (Chrysanthemoides monilifera ssp. rotundata) as an example. Ecology and Evolution, 7, 8643-8656

14. Raghubanshi, USA, Rai, LC, Gaur, JP, \& Singh, JS (2005). Invasive Alien Species and Biodiversity in India. Current Science, 88, 539-540

15. Sarifin, M., Sujana, I.P., and Pura, N.L.S. (2017). Identification and analysis of the weed population in paddy rice organic and inorganic in Jatiluwih village, district Penebel, Tabanan regency. Agrimeta, 7, 13 , 50-55

16. Irianto, G. (2016). Land and Food Sovereignty. Jakarta: PT. Gramedia Main Library

17. Cornelisson, G., Jubaedah., Nurida, N.L., Hale, S.E., Martinsen, E., Silvani, L., \& Mulder, J. (2018). Fading positive effect of biochar on crop yield and soil acidity growth during five seasons in an Indonesian Ultisol. Science of the Total Environment, 634, 561-568

18. Nayak, P.K., Nayak, A.K., Panda, B.B., Lal, B., Gautam, P., Poonman, A., Shahid, M., Tripathi, R., Kumar, U., Mohapatra, S.D., \& Jambhulkar, N.N. (2018). Ecological mechanism and diversity in rice-based integrated farming system. Ecological Indicator, 91, 359-375

19. Pambudi, P.A., \& Waryono, T. (2018). Life cycle assessment of dryland paddy farming in Ngadirojo District, Pacitan. E3S Web of Conferences, 74, 07001

20. Hulme, P.E. (2015). Invasion pathways at a crossroad: policy and research challenges for managing alien species introductions. Journal of Applied Ecology, 52, 1418-1424

21. Mardiyanti, D.E., Wicaksono, K.P., \& Baskara, M. (2013). Dynamics Diversity of Post-Rice Plant Species. Journal entry Crop Production, 1, 1, 24-35

22. Cornelisson, G., Jubaedah., Nurida, N.L., Hale, S.E., Martinsen, E., Silvani, L., \& Mulder, J. (2018). Fading positive effect of biochar on crop yield and soil acidity growth during five seasons in an Indonesian Ultisol. Science of the Total Environment, 634, 561-568

23. Nayak, P.K., Nayak, A.K., Panda, B.B., Lal, B., Gautam, P., Poonman, A., Shahid, M., Tripathi, R., Kumar, U., Mohapatra, S.D., \& Jambhulkar, N.N. (2018). Ecological mechanism and diversity in rice-based integrated farming system. Ecological Indicator, 91, 359-375

24. Choudhary, M., Datta, A., Jat, H.S., Yadav, A.K., Gathala, M.K., Sapkota, T.B., Das, A.K., Sharma, P.C., Jat, M.L., Singh, R., \& Ladha, J.K. (2018) , Changes in soil under conservation biology-based sustainable agriculture intensification of cereal systems in the Indo-Gangetic Plains. Geoderma, 313, 193-204

25. Kilkoda, AK, Nirmala, T., \& Widayat, D. (2015). Effect of the existence of weeds (Ageratum conyzoides and Boreria alata) against on the growth and yield of soybean (Glycine max L. Merr) variety of three sizes inlevel pot experiment. Cultivation Journal. 14, 2, 1-9

26. Zulharman. (2017). Foreign Invasive Plant Vegetation Analysis (Invasive Species) in Forest Revitalization Zone, Block Argowulan, Bromo Tengger Semeru National Park. Natural B, 4, 1, 78-87

27. Raghubanshi, U.S.A., Rai, L.C., Gaur, J.P., \& Singh, J.S. (2005). Invasive Alien Species and Biodiversity in India. Current Science, 88, 539-540

28. Nel, L., Pryke, J.S., Carvalheiro, L.G., Thebault, E., Veen, F.J.vE., \& Seymour, C.L. (2017). Exotic plants growing in a crop field margins provide little support to the mango crop flower visitors. Agriculture, Ecosystems and Environment, 250, 72-80

29. Gross, C.L., Whitehead, J.D., Souza, C.S.D., \& Mackay, D. (2017). Unsuccessful Introduced biocontrol agents can act as pollinators of invasive weeds: Bitou Bush (Chrysanthemoides monilifera ssp. Rotundata) as an example. Ecology and Evolution, 7, 8643-8656
30. Pattison, Z., Whytock., \& Willby, N. (2017). Invasion legacy versus sediment deposition effects as drivers of riparian vegetation. Biological Invasion

31. Ormsby, M., \& Rule, E.B. (2017). A review of global instruments to combat invasive alien species in forestry. Biological Invasion, 19, 3355-3364

\section{AUTHORS PROFILE}

Suyud Warno Utomo, received his Drs. in Biology from Gadjah Mada University in 1982, M.Si in Environmental Science from University of Indonesia in 1992, and Dr. in Environment and Population Planning from State University of Jakarta in 2002. Currently he is associate professor in the

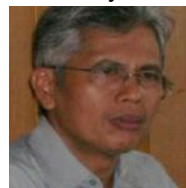
Department of Environmental Health, Faculty Public Health University of Indonesia and School of Environmental Science University of Indonesia. His area of expertice is environmental management and ecology.

Priyaji Agung Pambudi, received his S.Pd in Biology Education from Muhammadiyah University of Malang in 2017 and M.Si in Environmental Science from University of Indonesia in 2019. Currently working as researcher in University of Indonesia and as a doctoral student in

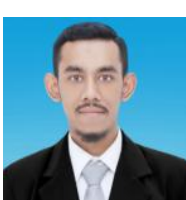
School of Environmental Science, University of Indonesia. His main research area is ecology and climate change. 